\title{
Fluorescein-conjugated Wisteria floribunda Lectin
}

\author{
National Cancer Institute
}

\section{Source}

National Cancer Institute. Fluorescein-conjugated Wisteria floribunda Lectin. NCI

Thesaurus. Code C148169.

\begin{abstract}
A fluorescein conjug ated to a preparation of lectin(s) extracted from the seeds of Wisteria floribunda (Japanese wisteria), with potential use as a diagnostic agent. Upon administration of fluorescein-conjug ated Wisteria floribunda lectin, the lectin moiety preferentially targets and binds to carbohydrate structures containing $\mathrm{N}$ acetylgalactosamine and galactose residues overexpressed on certain tumor cell surfaces. Using white and fluorescent light, tumor cells with increased lectin-binding affinity can be visualized or imaged.
\end{abstract}

